inOedia $\quad \begin{aligned} & \text { InMedia } \\ & \text { The French Journal of Media Studies }\end{aligned}$

$4 \mid 2013$

Exploring War Memories in American Documentaries

\title{
The Canadian Communication Tradition
}

4-7 June 2013, University of Victoria, British Columbia

\section{Christopher Ali}

\section{(2) OpenEdition \\ Journals}

Electronic version

URL: http://journals.openedition.org/inmedia/696

DOI: 10.4000/inmedia.696

ISSN: 2259-4728

Publisher

Center for Research on the English-Speaking World (CREW)

Electronic reference

Christopher Ali, «The Canadian Communication Tradition », InMedia [Online], 4 | 2013, Online since 08 November 2013, connection on 08 September 2020. URL : http://journals.openedition.org/inmedia/ 696 ; DOI : https://doi.org/10.4000/inmedia.696

This text was automatically generated on 8 September 2020.

(c) InMedia 


\title{
The Canadian Communication Tradition
}

\author{
4-7 June 2013, University of Victoria, British Columbia
}

\section{Christopher Ali}

\section{EDITOR'S NOTE}

Canadian Communication Association Annual Conference

\section{Canadian Communication Thought}

1 In his book, Canadian Communication Thought, Robert Babe argues for the recognition of a distinctly Canadian paradigm of communication studies. ${ }^{1}$ Grounding his observations in the scholarship of "ten foundational thinkers" - particularly Dallas Smythe, Harold Innis and Marshall McLuhan - Babe describes 'Canadian Communication Thought' as being inherently dialectical, critical, holistic, ontological, oriented towards political economy, and concerned with mediation, power, democracy and dynamic change. ${ }^{2}$

Dialectics and critical theory are at the forefront of this Canadian paradigm, representing the country's unique political and geographic terrain. Its dialectical predispositions stem from several factors including the country's embrace of British conservatism and a spirit of "collectivity and commonality;" its proximity to the United States and the differences between a "garrison mentality" of "communitarianism" in Canada and a frontier mentality of individualism in the US; and a geographic landscape that engenders both "bleakness" and "imagination." languages (English and French), cultures (a multicultural society with a visible First Nations population), and normative concerns for democracy, equality, and power further underscore a dialectical and critical tradition of hermeneutic inquiry. Accordingly, 
...foundational Canadian communication thought emphasizes the importance and the power of the human imagination, and it studies how our imaginations are moulded, or at least influenced, by prevailing institutions, by predominant media of communication, by our stories or myths, by our educational system, and by our place in the world. ${ }^{4}$

Proximity to the United States is another contributing factor to this dialectic Canadian identity as: "Canadians are normally immersed in American media, and so are quite aware of American perspectives, even while knowing that these perspectives do not necessarily represent accurately the Canadian situation." ${ }^{5}$ In concert, these aforementioned characteristics demarcate the Canadian communication research and scholarly experience and tradition as different and separate from that of the United States. Communications research in America (according to Babe) grew out of a tradition of studying 'transmission;' what Harold Lasswell called "administrative research," and exhibited an attitude that eschewed critical interrogation of the media industries which generate huge sums of individual and corporate capital in the country. ${ }^{6}$ In countenance to the United States, as Babe further observes, "for Canadians, democracy in part means resistance to hegemonic incursions from outside the country so of course Canadian scholarship, even in the mainstream, is more critical."7

4 Attending the Annual Meeting of the Canadian Communications Association (CCA) held in Victoria, British Columbia, in June 2013, one could not help but notice that these traditions remain the hallmarks of Canadian communication studies long after the passing of Innis, Smythe and McLuhan.

\section{The Canadian Communication Association in the Congress of the Humanities and Social Sciences}

5 Held annually, the CCA Conference brings together Canada's communication scholars and those from abroad as part of a larger event known as the Congress of the Humanities and Social Sciences. Organized by the Federation for the Humanities and Social Sciences, 'Congress' serves a unique function as an umbrella event for the annual meetings of over 70 associations of disciplines in the humanities and social sciences. This year's Congress, with the theme '@ the edge' was hosted by the University of Victoria and brought together thousands of scholars over eight days. Associations include everything from Sociology and Political Science, to the Canadian Association for the Study of Names, and, of course, the Canadian Communication Association. ${ }^{8}$

6 The CCA portion of Congress was held over three days, and featured 340 presentations by 386 researchers from Canada and the United States. Those unfamiliar to CCA may be interested to learn that the conference is bilingual, representing Canada's two official languages, with participants able to present in both English and French. With geography and landscape playing key roles in the development of Canadian communication thought, Victoria was a fitting setting for this conference, being literally 'at the edge' of Canada, and representing a site of inspiration for many Canadian artists and scholars. The University of Victoria did not fall short in this regard, and offered a breathtaking campus that combines natural and built environments.

7 As expected, universities from British Columbia - Simon Fraser University, The University of British Columbia, Royal Roads and University of Victoria - were well 
represented, as were several Quebecois institutions - l'Université Laval, l'Université de Montréal, Concordia University and l'Université du Québec. The University of Alberta also had a particularly strong showing given their lack of a communications or media studies programs.

The dialectical and critical theoretical trajectories outlined by Babe were keenly observed by the two keynote speakers. The first speaker, Dr Silvestra Marinello of l'Université de Montréal spoke about 'Exemplarity and Film' and discussed the discursive construction of film as exemplar of the human condition. The second keynote was given by Dr Arthur Kroker of the University of Victoria. In this address, titled 'Technologies of the Posthuman,' Dr Kroker spoke passionately about the intersection of bodies, society, and technology - both literal and figurative - and discussed the dystopic potentialities engendered within the digital age. Perhaps in no other presentation were the characteristics of critical theory and dialectical hermeneutic inquiry more strongly embodied than in Dr Kroker's lecture. While sometimes verging on the dense jargon of which critical cultural studies has been accused, Dr Kroker argued that we have entered the age of the 'Posthuman' wherein digital technologies occupy places of uncertainty and 'undecidability.'

9 Two awards are also handed out yearly at the CCA Conference. To encourage and promote Canadian communications scholarship, the Gertrude J. Robinson Book Prize recognizes the best book of the year published by a Canadian scholar as selected by a jury from nominations solicited throughout the year. In June, the Robinson Prize was awarded to Dr Bart Beaty from the University of Calgary for his book Comics versus Art (University of Toronto Press, 2012). Dr Beaty's book focuses on the shifting relationship between the supposedly 'low' culture world of comics and the institutions of the 'high' art world. The Beaverbrook Media@McGill Student Paper Prize, selected by a jury which includes the President of the CCA, recognizes the top student paper at CCA and in June was awarded to doctoral candidate Nora Draper of the Annenberg School for Communication at the University of Pennsylvania, for her paper "Rethinking Citizen photojournalism: Mediated Witnessing and the Obligations of Citizen Bystanders."

10 A particularly popular panel was that on Network Surveillance, Censorship and Privacy, where Nora Draper presented her award-winning paper which addressed the challenges engendered by the emerging identity of the 'citizen journalist' particularly in its (potentially dialectic) relationship to the State and to mass media. Draper used a case study of citizen journalism practices during and after the 2010 Vancouver Stanley Cup riots to support her argument, noting that concerns arise when citizen journalism is used as an element of surveillance. At the same panel, Dr Jonathan Obar from the University of Toronto gave a presentation on the 'IXMaps Project,' an innovative mapping tool used to track digital data packet transmissions. ${ }^{9}$ Dr Obar documented how in the milliseconds that it takes for data to get from one Canadian computer to another, many data packets (such as emails) are sent through servers in the United States, leaving them susceptible to the American Patriot Act and thus readable by American government agencies. This 'Boomerang Routing,' he contends, opens up numerous challenges to Canadian electronic and political sovereignty, Canadians' individual privacy, and suggests a larger political economic framework of digital data transmission in North America. ${ }^{10} \mathrm{Dr}$ Obar accentuated his presentation with a video that visually traced the flow of data packets from one Toronto office building to 
another via Chicago, therein demonstrating how even transmissions beginning and ending in the same Canadian city, often flow through American servers.

Policy analysis has been another hallmark of Canadian communication studies so much so that some have argued that 'policy studies' have become overly synonymous with Canadian communication studies (Wagman, 2010). ${ }^{11}$ Nonetheless, this vein of research represents important contributions to the Canadian scholarly corpus, and was the subject of several panels in Victoria. Of particular note was a proposal by University of Ottawa Professor Dr Jeremy Shtern to build an online platform that would support scholarship on Canadian communication policy issues in a more timely fashion than the traditional journal route. This faster turnaround would allow scholars to better contribute to ongoing policy and regulatory debates in a meaningful way. The online 'portal,' Shtern suggests, could be operated adjacent to the website of the Canadian Journal of Communication, with contributing articles falling somewhere between a policy report and an academic peer-reviewed article.

A bird's eye view of the 2013 CCA conference would suggest that the Canadian communications tradition is being well tended to by young scholars both within and outside of Canada. Ms Draper, Dr Obar and Dr Shtern, for instance, represent the new generation of innovative and dynamic Canadian communications scholarship, all the while embodying the foundations of Canadian communication thought as outlined by Babe. Nevertheless, one could also not help but note a distinct lack of senior faculty at CCA 2013. For Canadian scholarship to continue as a distinct and dynamic field within the larger domain of communication and media studies, senior and junior researchers must meet the challenges together; the spirit of collectivity and community - the 'garrison mentality' - so valued by early writers, embodied in both their scholarship and in practice. ${ }^{12}$

\section{BIBLIOGRAPHY}

Babe, Robert E. Canadian Communication Thought: Ten Foundational Writers. Toronto: University of Toronto Press, 2000.

Babe, Robert E. "Innis and the Emergence of Canadian Communication/Media Studies," Global Media Journal - Canadian Edition, Vol. 1, Issue 1, (2008): 9-23.

Hamilton, Sheryl N. "Considering Critical Communication Studies in Canada," in Mediascapes: New Patterns in Canadian Communication, edited by Leslie Regan Shade, 9-26. Toronto: Nelson Education, 2010.

IXmaps. http://www.ixmaps.ca/index.php <accessed on September 10, 2013>

Obar, Jonathan and Andrew Clement. "Internet Surveillance and Boomerang Routing: A Call for Canadian Network Sovereignty," SSRN Working Paper Series (2013). http://papers.ssrn.com/ sol3/papers.cfm?abstract_id=2311792 <accessed on September 10, 2013> 
Wagman, Ira. "On the Policy Reflex in Canadian Communication Studies," Canadian Journal of Communication, Vol. 35 (2010): 619-630.

\section{NOTES}

1. Robert E. Babe, Canadian Communication Thought: Ten Foundational Writers (Toronto: University of Toronto Press, 2000).

2. Hamilton (2010) makes the important rebuttal that we must be careful not to take such claims at face value, and instead must interrogate the nature of what it means to be 'critical,' and more importantly, what it means to be 'Canadian' (see also Wagman (2010) on these points).

3. Babe, Canadian Communication Thought, Chapter 1.

4. Babe, Canadian Communication Thought, 32.

5. Robert E. Babe, "Innis and the Emergence of Canadian Communication/Media Studies," Global Media Journal - Canadian Edition, Vol. 1, Issue 1, (2008): 19.

6. Babe, "Innis and the Emergence of Canadian Communication/Media Studies," 19.

7. Babe, "Innis and the Emergence of Canadian Communication/Media Studies," 19.

8. For more about the Federation for the Humanities and the Social Sciences, along with information about its annual meeting see: http://www.congress2013.ca/about-congress.

9. For more, see the IXmaps website at: http://www.ixmaps.ca/index.php.

10. See also Jonathan Obar and Andrew Clement, "Internet Surveillance and Boomerang Routing: A Call for Canadian Network Sovereignty," SSRN Working Paper Series (2013). http:// papers.ssrn.com/sol3/papers.cfm?abstract_id=2311792 <accessed on September 10, 2013>.

11. Ira Wagman, "On the Policy Reflex in Canadian Communication Studies," Canadian Journal of Communication, Vol. 35 (2010): 619-630.

12. Northrop Frye quoted in Babe, Canadian Communication Thought, 24.

\section{AUTHOR}

\section{CHRISTOPHER ALI}

University of Virginia 